suffused with a pinkish tint, evidently marking a period of cessation of growth, the colour having stained that part of the shell which then formed the lip of the aperture.

The uppermost dark band of the last whorl is situated a little above the middle, and passes just above the suture, and can be traced in part almost to the apical whorl. Adjoining this thin line there is a second thread-like one which borders the sutural edge of the whorls. The median band is very broad, frequently more than twice as wide as that above it, and encircles the whorl somewhat below the periphery; and the basal one, equally broad with the preceding, winds around the rounded margin of the umbilicus.
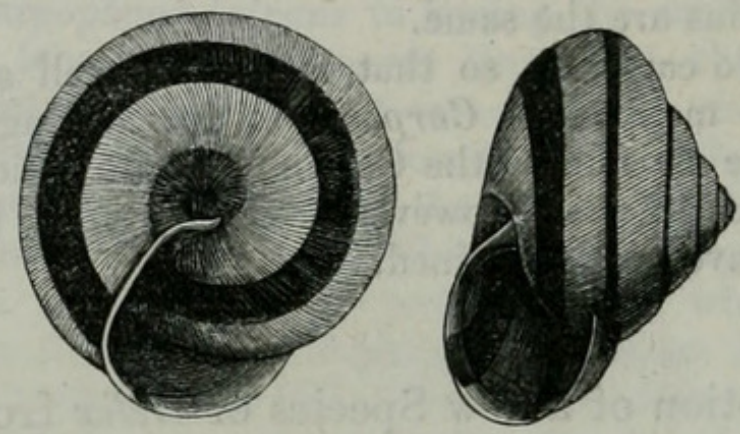

Helix (Camena) congener.

Other allied forms of this species are H. luhuana, Sowerby, which seems to be distinct from $H$. peliomphala, $H$. simoda, Jay, and $H$. herklotsi, Martens.

Whether these five are good and distinct species or only local forms of one and the same, of which intermediate gradations have not yet been observed, remains yet to be ascertained; but, so far as our present knowledge extends, the differences of form, texture, banding, \&c., warrant the presumption that they are specifically distinct.

The series of specimens upon which the above description is based has been kindly placed in my hands for examination by Mr. G. B. Sowerby, junior, who has presented two of them to the national collection.

10. Contributions to the Ornithology of the Philippines.No. IV. On the Collection made by Mr. A. H. Everett in the Islands of Dinagat, Bazol, Nipah, and Sakuyok. By Arthur, Marquis of Tweeddale, F.R.S., President of the Society.

[Received December 11, 1877.]

$$
\text { (Plates VI.-VIII.) }
$$

The four islands in which Mr. Everett collected the birds of which I propose to give an account are situated to the north of the 


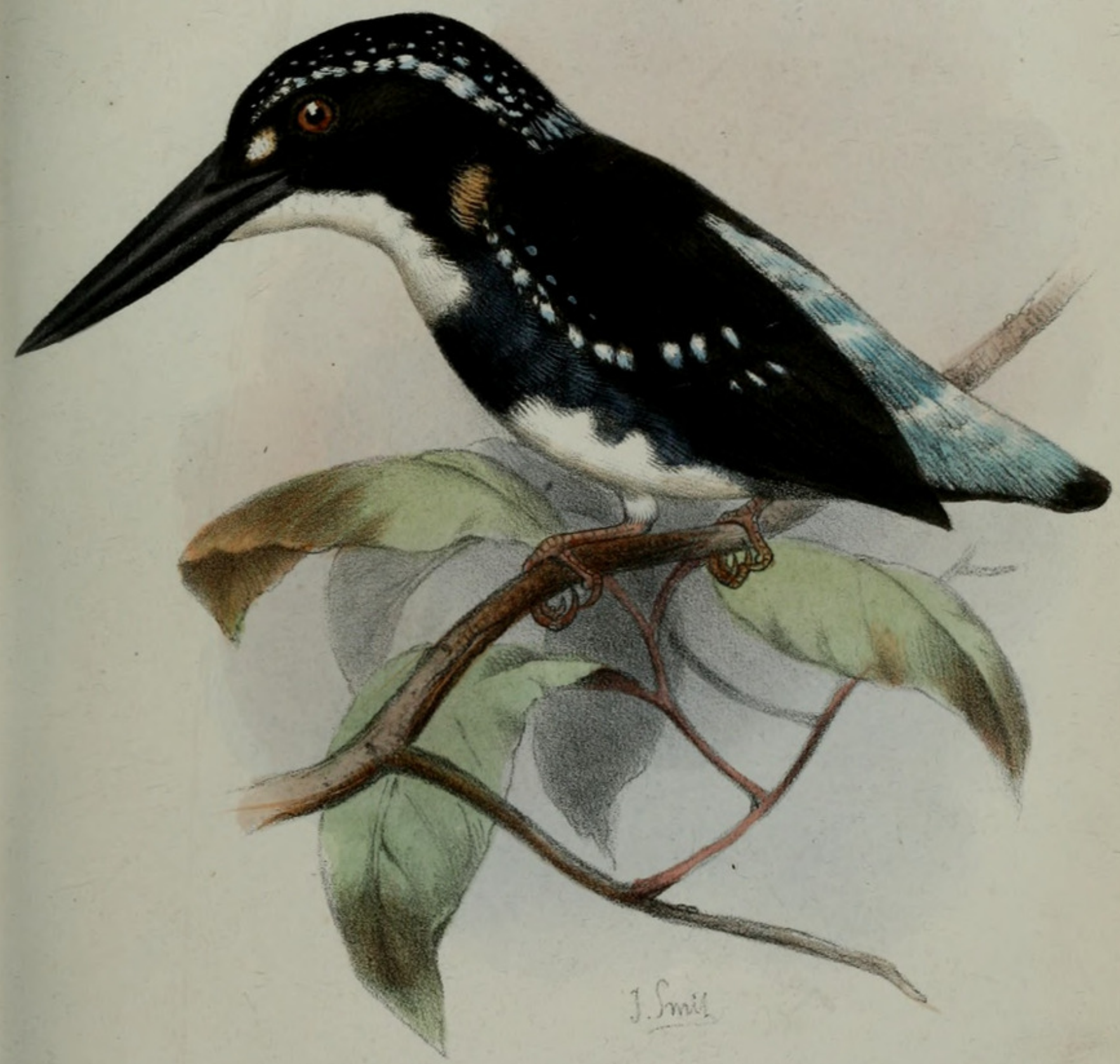

J Smit lith 


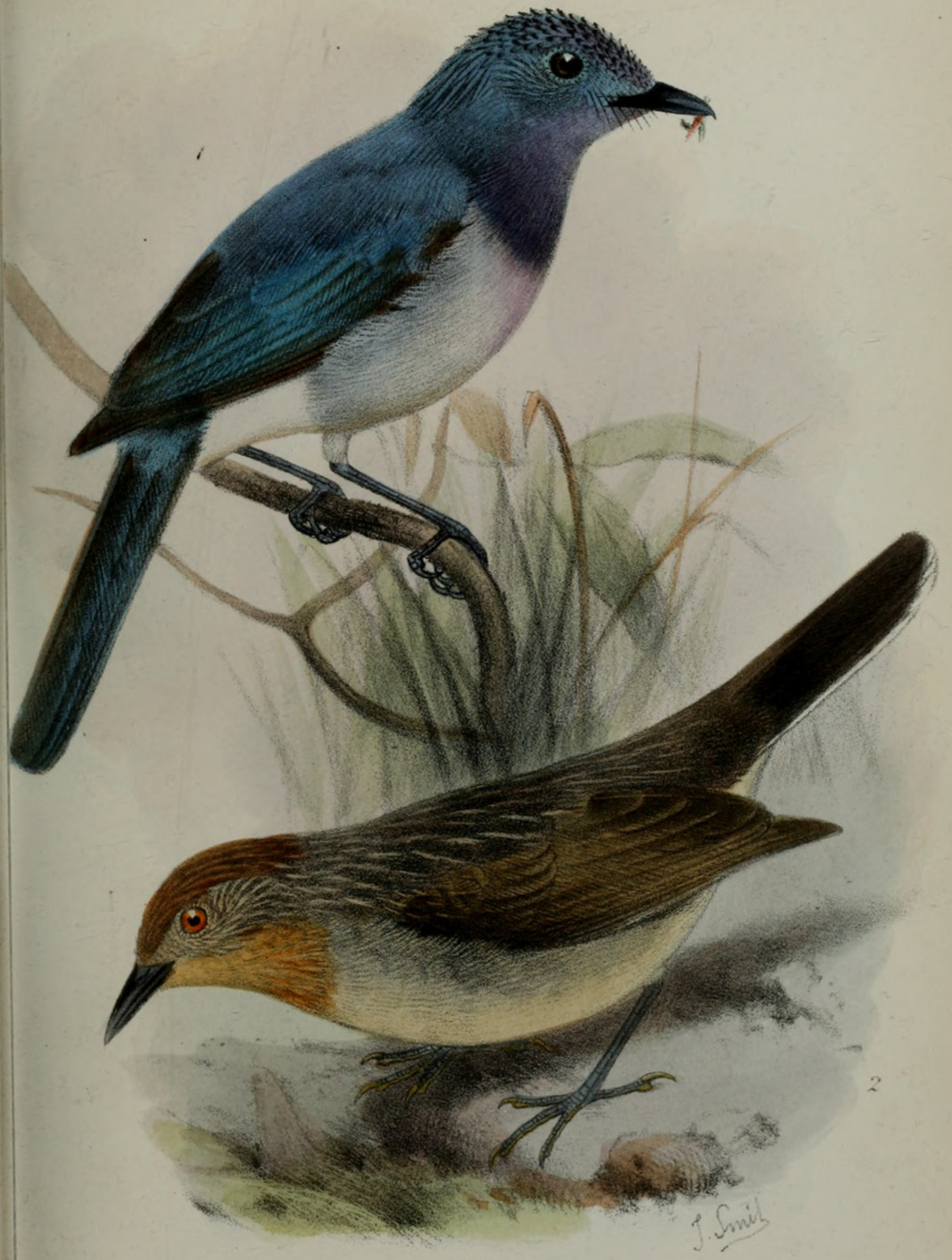




\section{P Z.S.1878.PI.VIII}

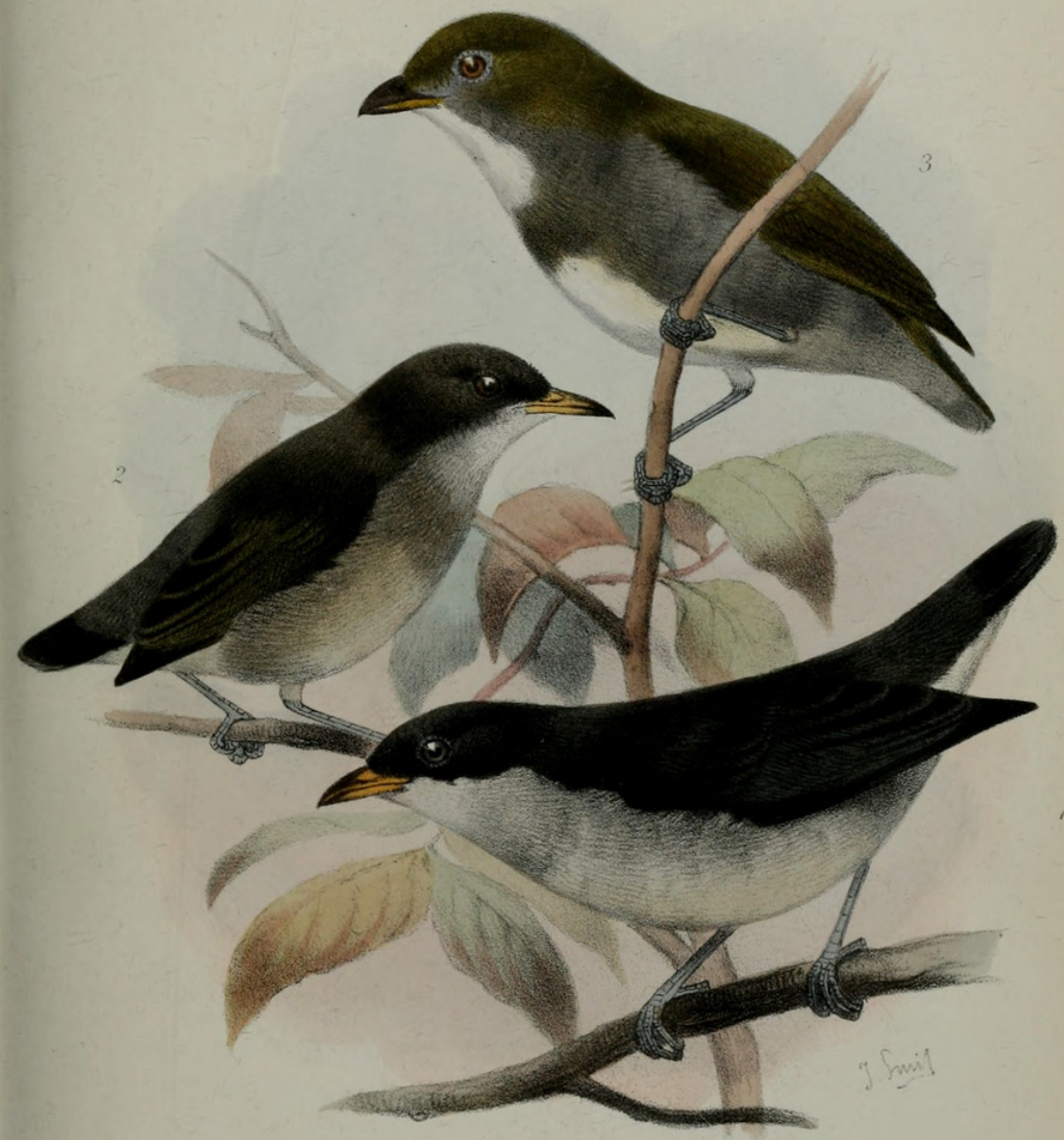

1.DICAUM SCHISTACEUM.

2.DICAUM EVERETTI.

3. PRIONOCHILUS OLIVACEUS 
shores of Mindanao, and are only separated from that island by narrow channels. Through these channels the wind blows with considerable force throughout the greater part of the year, being either the gales of the S.W. or the N.E. monsoon.

Mr. Everett's observations on the ornithological features of these islands, coming as they do from a personal observer, merit transcription. He writes :- " No district visited so far has equalled the vicinity of Manilla in the number and variety of its birds. The progress of the work shows that a very close general similarity exists between the islands of Mindanao and Luzon, though there are some marked local differences. This was to be expected; and it is rather surprising that the differences are as marked as they are, when we consider that not only are the islands separated from another by very narrow spaces of sea, but that they are situated in an area where strong winds blow in various directions, with little cessation during the major part of the year, accompanied with violent squalls and typhoons, so that any high degree of specialization in the local avifauna would seem, à priori, out of the question."

In the island of Dinagat, Mr. Everett writes, he found birds to be excessively rare ; still he obtained 39 species, 7 of which were undescribed :-

Ceyx argentata.

Hypothymis coelestis.

Mixornis capitalis.

Dicaum schistaceum.
Dicaum everetti.

Prionochilus olivaceus.

Athopyga dubia.

Only 13 species were obtained in the small islands of Nipah, Bazol, and Sakuyok; and they are all known inhabitants of Mindanao.

1. Cacatua hematuropygia (1).

[Nipah,, , July.]

\section{Loriculus hartlaubi (7).}

[a. Dinagat, $\sigma^{*}, q$, June. b. Bazol, ơ, July.]

The example figured, P.Z.S. 1877 , p. $819\left(\sigma^{\circ}\right)$, is in full adult plumage, the occipital feathers being orange-red, grading into orange on the nape, which colour suffuses and descends the back, losing itself in the pure green of the lower back. There is no blue about the face, chin, or throat; the dark blue of the under surface of the rectrices fades into pale blue at their apices. The orange hue on the back of the female figured is less intense.

\section{HARPACTES ARDENS (34).}

[Dinagat, $\sigma^{*}$, June. Iris brown; bill yellow, base green.]

A single example, in adult plumage, and which has a more massive bill than is found in Luzon individuals. Otherwise alike, and dimensions equal.

4. Merops phillppinus (35).

[Bazol, ơ, July.] 
5. Eurystomus orientalis (37).
$\left[a\right.$. Dinagat, $\delta^{\star}$, June.
b. Nipah, ㅇ, July.]

6. Pelargopsis gigantea.

Pelargopsis gigantea, Walden, Ann. \& Mag. Nat. Hist. (4) xiii. p. 123, P.Z.S. 1877, pp. 541, 822.

[Dinagat, $\rho$, $0^{*}$, June.]

Neither example in full plumage; and both are not separable from the Butuan male observed upon $l$. $c$. Butuan, Pasananca, Malanipa, and these Dinagat individuals appear to belong to a small race of P. gigantea.

\section{Ceyx argentata. (Plate VI.)}

Ceyx argentata, Tweeddale, Ann. \& Mag. Nat. Hist. (4) xx. p. 533 , ㅇ (1 December 1877).

[Dinagat, $q$, June. Iris brown ; bill black ; feet pale reddish.]

+ . Chin, throat, upper breast, abdomen, ventral region, major under wing-coverts, and thigh-coverts pure white. Cheeks, sides of head, and ear-coverts black. Lower breast and flanks black, washed with deep blue. Rectrices and under tail-coverts black. Plumage above black; a bold supercilium commencing above the eye and running into the occipital crest, formed by the component plumes being tipped with pale silvery blue; many of the feathers of the vertex minutely tipped with silvery blue. Occipital crest tipped with pale silvery bluish green, or silvery blue, or the two together. Dorsal plumage and lengthened upper tail-coverts black at base, then silvery bluish green, then pale silvery blue. Wings black. Major coverts each with a terninal silvery-green spot. Loral spot white; an isolated tuft on the sides of neck, white tipped with creamy fulvous. Bill black.

Wing $2 \cdot 62$ inches, tail $1 \cdot 37$, tarsus $0 \cdot 45$, culmen $1 \cdot 50$.

8. Sauropatis chloris (47).

[Dinagat, + , June.]

9. Pyrrhocentor melanops (65).

[Nipah, ㅇ, July.]

10. Penelopides affinis.

Penelopides affinis, Tweeddale, Ann. \& Mag. Nat. Hist. (4) xx. p. 534 ; P. Z.S. 1877 , p. 824.

[Dinagat, $\delta$, June : iris crimson. a. + , June: iris rather dark brown-orange.]

11. Graucalus striatus (74).

[Nipah, $\delta^{*},+$, July : iris Naples-yellow.]

12. Lalage dominica (76).

[Dinagat, $\delta$, $q$, June.] 
13. Hyloterpe philippinensis (78).

[Dinagat, $\delta$, June; $b$. 9 : iris dark brown; bill black; legs bluish grey.]

Sexes alike-not to be distinguished from the type.

14. Dicrurus striatus.

Dicrurus striatus, Tweeddale, P. Z. S. 1877, p. 545, no. 20.

[Nipah, ơ July.]

15. Leucocerca nigritorquis (83).

[Dinagat, + , June.]

\section{Cyornis philippinensis.}

Cyornis philippinensis, Sharpe, Tr. Linn. Soc. ser. 2, Zool. i. p. 325, "Panay" (1876).

[Dinagat, $\sigma^{*}$, June.]

A single example, hardly separable from Zebu individuals, and agreeing with them in dimensions, consequently larger than Luzon and North-Mindanao specimens. Wing 3.66 inches, as against $2 \cdot 95$; tail, $3 \cdot 00$, as against $2 \cdot 75$.

17. Нуротнумis cølestis. (Plate VII. fig. 1.)

Hypothymis coelestis, Tweeddale, Ann. \& Mag. Nat. Hist. (4) xx. p. 536, 우 (1 Dec. 1877).

[Dinagat, + , June : iris dark-brown; bill blue tipped and margined black; interior of gape yellow-green; orbital ring light green; legs grey blue.]

․ Azure. Feathers of the head grey at their insertion, and each tipped with glistening azure; a lengthened occipital crest similarly marked. Space before the eye and lores pale blue. Chin, cheeks, throat, sides of neck, and upper breast rich velvety turquoiseblue, darker than the blues of the rest of the plumage. Back and upper tail-coverts with grey bases to the feathers, the extremities being blue, which is paler on the upper tail-coverts. Wing-coverts of the same shade of blue as the head. Quills dark brown externally, margined with a paler shade of blue. Lower breast, abdomen, vent, flanks, and under tail-coverts white, tinged with pale greenish blue, most intense on the flanks. Axillaries grey, tinged with pale blue. Rectrices above like the quills; underneath dark brown like under surface of the quills. Shafts of the rectrices brown above, almost white underneath. Shoulder-edge blue.

Wing 2.82 inches, tail 3.00 , tarsus 0.62 , culmen 0.56 .

A form nearly allied to $H$. azurea, but differing in its lengthened crest, its paler tints of blue, and in the absence of any black markings. The blue shade of the throat and upper breast is about equal in tint to that of the predominant colour of the older known species.

18. Hirundo javanica.

Hirundo javanica, Sparrm., Mus. Carls. fasc. iv. t. 100 (1789).

[Dinagat, $\delta$, June.] 


\section{Sarcophanops STEERII.}

Eurylamus steerii, Sharpe, 'Nature,' vol. xiv. p. 297. "Basilan.” Sarcophanops steerii, Sharpe, Tr. L. S. ser. 2, Zool. i. p. 344, t. liv.

[Dinagat, $q$, June : iris brilliant sap-green; bill, orbital skin, and legs fine blue, paler on the tarsal scales; nails light grey.]

20. Broderipus ACrorhynchus (90).

[Dinagat, $\delta^{*}$, June.]

21. Mixornis capitalis. (Plate VII. fig. 2.)

Mixornis capitalis, Tweeddale, Ann. \& Mag. Nat. Hist. ser. 4, xx. p. 535 (Dec. 1, 1877).

[Dinagat, + , June : iris orange; bill blackish grey; legs greenish lead-grey ; soles and nails ochreous yellow.]

. Forehead, vertex, and occiput rufous, each feather with a pale fulvous central streak. Space before the eyes and lores dull grey. Cheeks, ear-coverts, and sides of neck ashy, each feather with a pale albescent central streak. Nape, back, and wing-coverts the same, the pale striations on the back being very prominent in consequence of the abnormal length of the dorsal plumage. Uropygium and upper tail-coverts olive rusty grey and unstriated. Rectrices brown; outer pair with the whole outer and apical third of the inner web pale yellowish white; remaining pairs, middle excepted, broadly tipped on both webs with white, middle pairs slightly tipped with white. All the quills brown, narrowly margined externally with fulvous grey, the tertiaries with pale rusty. Basal portion of quills margined on their inner webs with white. Chin and throat rufous and rufous-white. Breast, under wing-coverts, abdomen, vent, and under tail-coverts white, faintly tinged with very pale yellow.

Wing $2 \cdot 75$ inches, tail $2 \cdot 50$, tarsus $0 \cdot 70$, culmen 0.62 .

\section{Macronus striaticeps.}

Macronus striaticeps, Sharpe, Tr. L. S. ser. 2, Zool. i. p. 331, “Basilan” (1876).

[Dinagat, ㅇ: iris white.]

The type specimen is not quite so rufous below, otherwise identical.

23. Ixus goiavier (99).

[Nipah, + , pairing, July.]

24. Poliolophus urostictus (101).

[Dinagat, $\delta$, June: orbital ring lemon-yellow. $b$, $q$, June.] Sexes alike.

25. Criniger everetti.

Criniger everetti, Tweeddale, Ann. \& Mag. Nat. Hist. ser. 4, vol. xx. p. 535, et P. Z.S. 1877 , p. 827 , pl. lxxxiv.

[Dinagat, $\delta, ~ \&$, June.] 


\section{Orthotomus frontalis.}

Orthotomus frontalis, Sharpe, Ibis, 1877 , p. 112, t. ii. f. i. ; Tr. L. S. (2) Zool. i. p. p. 336.

[Dinagat, $0^{*},+$, June.]

\section{Zosterops eVEretti.}

Zosterops everetti, Tweeddale, P. Z. S. 1877, pp. 762, 829.

[Dinagat, $\delta$, June : iris yellowish brown; bill blackish; legs pale grey. $b$, $q$, June.]

Dinagat, North-Mindanao, and Zebu birds do not differ.

28. Diceum rubriventer (120 partim).

Diccum rubriventer, Lesson, Tr. p. 303; Tweeddale, P.Z.S. 1877 , p. 763.

[Dinagat, ơ, June.]

The Dinagat birds in no respect differ from Luzon, Zebu and North-Mindanao examples.

29. Dicaum schistaceum. (Plate VIII. fig. 1.)

Dicaum schistaceum, Tweeddale, Ann. \& Mag. Nat. Hist. ser. 4, vol. xx. p. 537 (December 1, 1877).

[Dinagat, $\sigma^{*}$, June.]

${ }^{*}$. Above fuliginous ashy; below ashy white. Remiges and rectrices above dark ashy brown, underneath paler. Under wingcoverts and axillaries pure white. Base of mandible (in dry specimens) yellowish white. Apex and the maxilla pale ruddy brown.

Wing $2 \cdot 25$ inches, tail $1 \cdot 37$, tarsus $0 \cdot 62$, culmen $0 \cdot 35$.

A large species with a short stout bill.

30. Dicaum everetti. (Plate ViII. fig. 2.)

Dicaum everetti, Tweeddale, Ann. \& Mag. Nat. Hist. ser. 4, vol. xx. p. 537 (December 1, 1877).

[Dinagat, ơ , June: iris greyish brown; bill brown, base orange; legs light grey.

o. Above dark olive-green, paler on the cheeks. Chin, throat, and breast pale grey. Remainder of underparts albescent grey tinged with palish yellow. Major coverts narrowly margined with greenish yellow. Quills above dark brown, almost black, with very narrow pale olive-green external margins. Rectrices above like the quills, narrowly tipped with albescent fringe. Under wing-coverts and axillaries pure white. Bill (dry specimen) brown at tip, yellow at base.

Wing 1.94 inch, tail 1.00 , tarsus 0.50 , culmen 0.37 .

31. Prionochilus olivaceus. (Plate VIII. fig. 3.)

Prionochilus olivaceus, 'Tweeddale, Ann. \& Mag. Nat. Hist. ser. 4, vol. xx. p. 536 (December 1, 1877).

[Dinagat, $q$, June : iris sienna-brown; bill grey-black, base of mandible paler; legs light grey.] 
․ Entire upper surface, wing-coverts, and surface of closed wing uniform pure olive-green, which colour encircles the eye and covers the sides of the neck. Space before the eye, cheeks, sides of throat, and the upper breast grey. Lower breast, abdomen, flanks, and under tail-coverts the same grey washed faintly with olive-green, the mesial line being albescent. Chin and throat white, slightly greyish, forming a broad well-defined greyish white stripe, commencing at the chin and descending to the breast. Axillaries and under wing-coverts pure silky white. Remiges and rectrices dark brown, margined with the olive-green hue of upper plumage.

Wing $2 \cdot 12$ inches, tail $1 \cdot 25$, tarsus $0 \cdot 62$, culmen 0.37 .

Since I described this species $(l . c$. $)$ I have received the male, which in no way differs.

\section{Nectarophila sperata (122).}

[Dinagat, $\delta^{\star}$, June; $b$, $q$ : iris brown; bill very dark brown; legs black. $c$, June : iris dark brown; bill black, mandible brown; legs black. $d$, o (juv.), June : iris dark brown. $e$, Nipah, $\delta$, July.]

I cannot separate example $d$ ( $\sigma^{\mathrm{j} j u v}$.) from examples $b$ and $c$ ( $q$ ). A slight supercilium, chin, throat, cheeks, and whole lower surface pale uniform greenish-yellow, above olive-green. They differ from a supposed female, ex Surigao, described (P. Z. S. 1877, p. 830) by having the chin, throat, and cheeks uniformly coloured with the breast and abdomen, but agree in the ruddy colouring of the wing when closed. A fourth example (sex not stated on label) is undistinguishable from the Surigao female previously described (l.c.).

\section{Arachnechthra jugularis (123).}

[Dinagat, + , June.]

\section{- 34. Æthopyga dubia, n. sp.}

[Dinagat, $\sigma^{\dagger}$, June: iris yellow-brown; bill brown; legs dark grey; feet ochreous. $b, o^{*}$, June : bill and legs very dark brown. $c$, , June : iris bright Indian-red ; bill black ; legs light brown.]

$\delta$ (juv.?). Above, wing-coverts, and exposed surface of quills olive-green. Uropygium bright sulphur-yellow, forming a broad yellow band. Rectrices black, edged with olive; laterals tipped with pale yellow-olive. Feathers of the lower surface ashy at their base, and all tipped pale yellow; lores the same; cheeks rather albescent-ashy. Under wing-coverts white; carpal edge very pale yellow. Quills dark brown.

․ Like the male above described.

\begin{tabular}{|c|c|c|c|}
\hline Wing. & Tail. & Tarsus. & Culmen. \\
\hline రే 1.82 & $1 \cdot 12$ & $0 \cdot 62$ & $0 \cdot 75$ \\
\hline $1 \cdot 80$ & 1.00 & 0.62 & $0 \cdot 75$ \\
\hline
\end{tabular}

The three examples on which this species is founded are difficult to distinguish, by their plumage alone, from $A$. bella $q$ vel $\sigma$ 
juv.; but the dimensions are considerably greater :-culmen $0 \cdot 75$, as against 0.50 ; wing $1 \cdot 80$, as against $1 \cdot 62$. Doubtless the adult male will closely resemble that of $\mathcal{E}$. bella.

35. Anthothreptus griseigularis.

Anthothreptus griseigularis, Tweeddale, P. Z. S. 1877 , p. 830 .

[Sakuyok, o*, July.]

36. Rhabdornis mystacalis (124).

[a. Dinagat, $\sigma^{*}$, June : iris crimson; bill black. b. $\sigma^{*}$ : legs yellowish brown. $c$. $\delta^{*}$ : legs dark grey.]

The only female in a series of seven examples wears the same dress as the males. Luzon individuals do not differ.

37. Corvus philippinus (125).

[Dinagat, o*, ㅇ. ]

Female smaller than male.

38. Calornis panayensis (128).

[a. Nipah, $\sigma, q$, July. b. Sakuyok, $q$, July.]

39. Sarcops CaLvUs (129).

[Dinagat, ơ, June.]

40. Osmotreron axillaris (136).

(Dinagat.)

A single example ( $\sigma^{*}$ ), which cannot be separated from typical individuals.

41. Phabotreron amethystina (139).

[Dinagat, 오 , June : iris yellowish brown.]

This, Luzon, and N. Mindanao (Butuan) examples do not differ.

42. Phabotreron brevirostris.

Phabotreron brevirostris, Tweeddale, P.Z.S. 1877, p. 549.

[Dinagat, + , May.]

Undistinguishable from N. and S.W. Mindanao examples.

43. Carpophaga enea (141).

[Dinagat.]

44. Myristicivora bicolor (143).

[a. Nipah, + , July : iris dark brown; bill blackish blue; feet light lead blue. $b$. Sakuyok, $\delta$, July.]

45. Hemiphaga poliocephala (144).

[Dinagat, + , June. Iris Indian-yellow, passing into red on outer circumference; orbital ring and patch crimson; bill black; feet carmine; nails dark grey.]

Proc. Zool. Soc.-1878, No. VIII. 
46. Ortygometra cinerea (I 72 ).

[Dinagat, + , June : iris crimson.]

47. Hypotenidia torquata (177).

[Dinagat, + , June.]

48. Butorides javanica (197).

$\left[a\right.$. Dinagat, $q ; b$. Nipah, $0^{*}+$, July : iris bright yellow; legs bright chrome-yellow.]

No date on label of Dinagat example, but killed in June.

49. Dysporus sula (214).

[Dinagat, $\sigma^{*}$, June : iris white; feet light leaden-green ; bill whitish green.]

In full white and rich brown plumage. Wing $15 \cdot 30$, tail $10 \cdot 00$, culmen $3 \cdot 90$, tarsus $1 \cdot 60$.

11. On a new Philippine Genus and Species of Bird. By Arthur, Marquis of Tweeddale, F.R.S., President of the Society.

[Received December 12, 1877.]

\section{(Plate IX.)}

Until Dr. Steere some three years ago discovered in the island of Basilan two species ${ }^{1}$ belonging to the Timeliidce, this natural family, so characteristic of the Indian region, was supposed to be unrepresented in the Philippines. Since then Mr. Everett has discovered a third species ${ }^{2}$ in the island of Dinagat, and a fourth, the subject of this note, in the island of Negros. This last bird is so anomalous in its structure that I propose to constitute it the type of a new genus,

\section{DASYCROTAPHa ${ }^{3}$.}

Base of maxilla densely clothed with short feathers, space behind the eye naked. Bill about the length of head, and formed as in Mixornis. Wing lengthened, longer than tail, first primary half the length of the second, which is a fifth shorter than the third, third a little shorter than the fourth, which is equal to fifth and sixth. Tail moderate and square. Tarsus strong; hallux with claw stout and long; digits short, slender ; outer a little shorter than inner.

\section{Dasycrotapha speciosa, sp. nov. (Plate IX.).}

Head crested; forehead with dense short plumes covering the base of the maxilla ; circle round the eye, whole space before the eye, tuft on the side of the base of mandible, chin and uppermost

I Macronus striaticeps, Sharpe, and Dendrobiastes basilanica, Sharpe.

a Mixornis capitalis, Tweeddale.

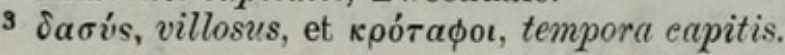




\section{$2 \mathrm{BHL}$ Biodiversity Heritage Library}

Tweeddale, Arthur

Hay,

I

. 1878. "Contributions to the Ornithology of the Philippines.-No. IV. On the Collection made by Mr. A. H. Everett in the Islands of Dinagat, Bazol, Nipah, and Sakuyok." Proceedings of the Zoological Society of London 1878, 106-114. https://doi.org/10.1111/j.1469-7998.1878.tb07936.x.

View This Item Online: https://www.biodiversitylibrary.org/item/90438

DOI: https://doi.org/10.1111/j.1469-7998.1878.tb07936.x

Permalink: https://www.biodiversitylibrary.org/partpdf/73464

\section{Holding Institution}

Natural History Museum Library, London

\section{Sponsored by}

Natural History Museum Library, London

\section{Copyright \& Reuse}

Copyright Status: Public domain. The BHL considers that this work is no longer under copyright protection.

This document was created from content at the Biodiversity Heritage Library, the world's largest open access digital library for biodiversity literature and archives. Visit BHL at

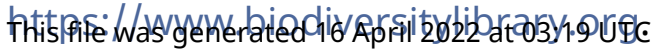

